УДК $159.9 .01: 167 / 168$

doi: $10.15330 / p s .10 .1 .5-21$

Анатолій В. Фурман

Тернопільський національний економічний університет

a.furman@tneu.edu.ua

\title{
МЕТАТЕОРЕТИЧНА РЕКОНСТРУКЦІЯ ПРЕДМЕТНОГО ПОЛЯ КАНОНІЧНОЇ ПСИХОЛОГІЇ
}

Наука як сфера пізнавальної творчості та духовного продукування раціонального знання фундується на розлогій сув'язі самобутніх правил, норм, канонів (гр. капоп - правило), щзо вироблені й апробовані достойниками людства упродовж століть. Пропоноване методологічне дослідження присвячене аналітичному відновленню і рефлексивному обгрунтуванню предметного поля канонічної психології як одного $з$ вершинних творчих здобутків видатного українського психолога-мислителя другої половини ХХ століття академіка Володимира Андрійовича Роменця (1926-1998). Новизна здійсненого епістемного поступу стосується кількох аспектів конструктивного розв 'язання зазначеної проблеми: по-перше, канонічна психологія розглядається як післядіяльний інтеграчійний підсумок розвитку трьох базових теоретичних джерел або дисииллін - історії всесвітньої психології, загальної психології $і$ численних психологічних теорій окремих психічних феноменів-подій (установки, ставлення, несвідомого, пережсивання, гри, особистості та ін.), тобто вона на метатеоретичному рівні знімає (заперечує і водночас зберігає у трансформованій подобі) їхній зміст у більи ємному, синтетичному, ущільненому вигляді; по-друге, відповідно до великої складності висвітлюваної проблеми підбирається адекватний способу ї̈ розв'язання багатомодульний інструмент циклічно-вчинковий підхід, методологічна оптика якого містить чотири принципи, шість закономірностей $і$ низку похідних нормативів розгортання рефлексивної миследіяльності; по-третє, підлягають аналізу й узмістовленню чотири головних сегменти упредметнення канонічної психології: як філософськопсихологічного напряму розвитку сучасного людинознавства, як науково-світоглядний «перехід від ХX до XXI століття у психологічному думанні», як метасистема фундаментальних (основоположних стосовно засновків і сутності людського буття) психологічних знань, як головна течія розвитку теоретичної психологї інтелектуальними і семантичними засобами ї̈ саморефлексї; по-четверте, канонічна психологія, зосереджуючись на вивченні та конструюванні взіриевих феноменів $і$ подій людського життя, набуває культурної вагомості як своєрідна світоглядна постава чи метапозиція бачення та осягнення психічного. Відтак висновується, щзо зазначений академічний напрям має поліаспектний, багатосегментний предмет, щуо сукупно входить у предметне поле теоретичної психологї. Він, як надскладна філософсько-психологічна метатеоретична конструкиія, охоплюе «всі визначні теорії, щуо виникли в історико-психологічному дискурсі», надаючи їм справжнього, засвідченого вчинковою подієвістю, смислу пізнання. Насамкінець окреслюється чотириіпостасний структурно-функиіональний изикл будь-якого логічно зрілого психологічного канону, щуо упрозорюе як тендениію-процедуру канонізації психічних феноменів, так $і$ збагачує теоретичний світ канонічної психології. Доводиться, щзо цілком аргументованим у творчому досвіді натхненного пізнання для В. А. Ромения, універсальним й абсолютно достатнім у свойх можливостях орієнтиром-засобом чи навіть світоглядом є психософія вчинку як методологія дослідження джерел, сутності і канонів-узіриів людського буття, як дійсне -відповідально вчинкове - взаємопроникнення психології $і$ філософії мудрості, врешті-решт як універсальний алгоритм $і$ методологічна схема буттєвого поступу людини до повнокомпонентного вчинку, до розгорнутого, особистісно натхненного і просякнутого лабільним розумом, учинення.

Ключові слова: канонічна психологія, циклічно-вчинковий підхід, предметне поле, рефлексивне методологування, світ теоретичної психології, методологічне знання, метапозиціювання, метатеорія, канонізація теоретичних систем, психологічний канон, психософія вчинку, В. А. Роменець, П. А. М'ясоїд.

Постановка проблеми в загальному вигляді та її зв'язок із важливими науковими завданнями. В кількасотлітній історії розвитку психологічної науки учені-мислителі прагнули надати сутнісної визначеності тій психології, яку вони обгрунтовували, вживаючи для цього прикметники задля якісного розрізнення дослідницьких стратегій психологічного думання-теоретизування. Так, власне, виникли й здобули більше чи менше утвердження загальна та експериментальна, описова й пояснювальна, глибинна та аналітична, поведінкова і гештальтна, інженерна і соціальна, диференціальна і когнітивна, клінічна і спеціальна, сцієнтистська і прикладна, гуманістична й екзистенційна та інші численні дисциплінарні розгалуження психології. Автором ідеї та парадагмальної планкарти канонічної психології є видатний мислитель другої половини ХХ століття, фундатор 
української історико-психологічної науки і творець філософсько-психологічної теорії вчинку Володимир Роменець.

Петро М'ясоїд, будучи найбільш послідовним, добровільним і компетентним наступником-популяризатором ідей, концептів, теорій та світоглядних канонів В. А. Роменця, абсолютно правильно вказує на те, що історична і теоретична лінії культурно вагомої творчості останнього «переплітаються, одна переходить в іншу, збагачуючи і розширюючи сферу пояснювальних можливостей теорії вчинку, зрештою, об'єднуються ідеєю канонічної психології - дисципліни, предметом якої є людське самопізнання і переображення. Канон - це вчинкового характеру взірці історичної поведінки людини, що складаються у процесі пошуків нею сенсу буття, визначені відношенням «поцейбічне - потойбічне» та похідним від нього «абсолютне - конкретне», «універсальне - оригінальне», «тоталітаризм - незалежність...» [9, с. 104]. I справді, Володимир Андрійович викристалізував ідею канонічної психологї̈ в останні роки життя, що засвідчують післямова до колективно підготовленого підручника «Основи психології» $(1995)$ і три розділи $(38,39$, 40) шостої (останньої) частини навчального посібника «Психологія XX століття» [12, с. 877-930], що вийшла у світ після його відходу у вічність у співавторстві з I. П. Манохою. Закономірно, що в цих творах він формулює низку дефініцій, інваріантних упредметнень і постулатів на кшталт: подія, що «визначає собою сенс людського життя... стає взірцевою, архетипною, ортопсихічною, зрештою - канонічною...»; «Психологія, що звертає свій погляд на такі взірцеві феномени, називається канонічною психологією»; «В широкому розумінні каноном дослідження виступають різні принципи, що постали в історії психології...»; «Поле психологічного дослідження 3 позицій канонічної психології охоплює індивідуальну, соціальну та історичну активність людини, де вона виявляє себе найповнішим чином. Ці три площини людського буття згортаються в єдиний феноменологічний канон...»; «Відчувається потреба в напрямі психології, в якому відображається не життєвий або творчий шлях, а корінні мотиви буття у їхньому взаємному зв'язку та відповідні форми поведінки. С підстави назвати таку психологію канонічною»; «Те, що людина поєднує в собі два світи, виражається в іiї очах, і ці великі очі подиву, неспокою, страху, очікування є також психологічним каноном...»; «Проповідь теж потребує авторитету, й ним виступає, зокрема, засновник релігії, і саме в цьому разі ідея канону постає в усій своїй чистоті...»; «...справжня оригінальність торкається таких глибин людського буття, де світиться єдність буттєвої долі. Лише в поверховому люди роз'єднуються. Лише в найглибшому своєму бутті вони єдині. Але воно затьмарюється, як правило, пристрастями буденності, які у своїй зв'язаності дають хибне коло взаємодії. Мовиться про канонічний ряд відносин...»; «...Можна говорити про феномен Сократа, постать і доля якого становить яскравий канон смертної кари за висунення нових всезагальних канонів моралі у їх протиставленні глибоким традиційним звичаям, не писаним ніким, які, проте, як фатум, керують людською долею, вчинками - тому й підводяться під стародавній канон поведінки...»; «Найвиразніша постать, що втілює собою образ шляху до смерті, а далі - до безсмертя, $\epsilon$ Ісус Христос...»; «Акти, які викликають легенду, говорять про легендарну, або героїчну, особистість. Ї̈̈ постання є вираженням канону людського буття...»; «існування архетипів колективного несвідомого..., без сумніву, - один із найтиповіших проявів психологічного канону, який формує вже розвинені типи не тільки поведінки, а й світогляду і мови»; «Народ визначається тим, як і яку культуру він виробляє, і вона зрештою стає каноном його способу життя. Культура... є тим, що виявляється у різних формах творчості, - своєрідністю стилю виробництва окремих цінностей, їхнім архетипом. Цей apхетип народного духу як універсальний канон життя визначає характер включеності людини у світ, характер «паль буття», пов'язаний з визнанням тих або інших цінностей...» «...Знову і знову постають есхатологічні питання, питання індивідуального буття людей, питання їхнього історичного існування. I це вічне історичне очікування кінця світу породжує своєрідні канони поведінки» та ін. [11, с. 605-608, 610, 613-617, 620]. В усвідомленні єдності існування опору і смислу буття «постають засади психології, що запе- 
речує психологію гуманістичну з іiі суб'єктивізмом і взаємною ненавистю, такої психології, яка через індивідуалізм, неповторність дає людині можливість рухатися до всезагального, відчути безконечне духовне багатство, у якому взаємодіють і взаємозбагачуються всі індивідуальності. Це психологія канонічна; вона здолала однобічність попередніх психологій і вказала на синтез індивідуального і всезагального...»; «Отже, канон не $\epsilon$ якоюсь метафізичною, потойбічною сутністю, це - рушійна сила та взірець психологічного знання, яке розгортається на грунті вчинкового осередку психологічної системи. Вчинок є каноном психологічного знання, адже у самому вчинку, у самому вчинковому осередку перебуває канон»; «...Кожна психологічна теорія або напрям мають пройти ці стадії [розвитку], які вже висвітлюють великий канон. I саме канонічна психологія має вміщувати у своїй безмежній і разом 3 тим чіткій формі все багатство творчих пошуків у психологічній теорії загалом»; «Феноменологічний метод канонічної психології дає справжню творчу новизну, яка не розгортається із згорненого, а постає як дещо зовсім оригінальне і не закладене споконвічно... Водночас канон ніколи не може бути пояснений до кінця. Це щось аксіоматичне, проте живе й рухливе у своєму сутнісному прояві...»; «Канонічна психологія постає по суті як своєрідна позиція бачення та осягнення психічного», яка в результативному вимірі його нескінченних зрізів уміщує безконечну кількість психічних феноменів; «Провідна ідея канонічної психології полягає в тому, щоб, уникнувши створення системи «нових заміщень» [«ідеальне $\epsilon$ схематичним заміщенням реального»] психічного, індивідуальності, людини (в усій повноті ії виявів), запропонувати систему ідентифікацій і тлумачних характеристик свого предмета через ідею, статус і розгорнутий зміст канону»; логічна структура психологічного канону має чотириіпостасну будову (див. далі); «Канонічною буде така психологія, що в кожному психологічному феномені відшукуватиме тенденцію руху саме до канону.., та й кожний психічний феномен «можна піднести до рівня канону. Це вимога не теоретичної психології, а вимога життя»; «Канон водночас «прагне» до чуттєвості і до подолання іiі, тобто до трансцендентності (потойбічності) і посейбічності» та ін. [12, с. 880, 882, 885, 890-891, 898-899, 930].

Таким чином, В. А. Роменець під завісу XX століття чітко окреслив предметні рамки новостворюваної ним канонічної психологї̈ як методологічно відмінної від усіх наявних стратегії психологічного думання. Ця психологія у його світоглядних настановленнях становить підсумок, заперечення й одночасно синтез на якісно досконалішому метатеоретичному рівні аналізу сцієнтистських і гуманістичних, а також суто науково-раціоналістичних в лоні людинознавства спрямувань психології, аргументує ії передісторію і вказує на витоки, які вбачає у низці провідних напрямів - емпіричного, раціонального, феноменологічного, екзистенційного, критикує неканонічні системи психології, загальною вадою яких є прагнення-тенденція набути науковості шляхом зведення вищого до нижчого. Причому це характерно не тільки для природничо-наукових зорієнтувань, а й для психоаналізу в цілому, незважаючи на намагання його представників долучити до вивчення людської психіки соціальну атрибутику.

Аналіз останніх досліджень і публікацій, у яких започатковано розв'язання окресленої проблеми. Крім вище окресленого мережива визначень і постулатів канонічної психології, відпочатково сформульованих В. А. Роменцем, донині реінтерпретаційні лакуни предметного поля цього новітнього напряму розвитку психологічної науки містять тільки праці одного учня-наступника Володимира Андрійовича - Петра М'ясоїда (1950 р. н). Примітно, що це стосується як його наукових творів [9, с. 99-104, 167-179; 7, с. 49, 41-43, 443-453, 459-460; 8, с. 29-30, 137-139], так із навчальної літератури для здобувачів вищої освіти зі спеціальності «Психологія» [6, т. 1, с. 163-167, 486-489, 6, т. 2, с. 672-675]. Загалом в обох випадках - першоджерела і його розтлумачення - отримано спільний вирішальний висновок: всі наявні до кінця XX століття неканонічні вчення, напрямки, теоретичні системи психології методологічно грунтуються на хибному принципі тлумачення, суть якого полягає у відшукуванні простої одиниці, до якої можна було би звести все 
багатство психічних феноменів. Таке тлумачення, на його переконання, є рухом назад, адже залишається питання: як же бути зі зворотною функцією - виведенням із цього простого, елементарного - складного, повноцінно життєвого? Всі так звані елементи, одиниці, осередки тощо дають [усього-на-всього] картину зведення (до рефлексів, асоціацій, навичок і т. ін.) [12, с. 890]. Відтак методологічна позиція академіка Роменця альтернативна - досліджувати психічне і психічні явища у їх якомога більш довершеній цілісності - у подієво-взірцевих, власне канонічних, формах та зорганізованостях, себто у їх буттєвій повноті, достатній феноменальній оприявненості, в неподільному зв'язку й функціональному збалансуванні з іншими психологічними канонами. Тому він, зважаючи на сказане, схвально ставиться та високо оцінює значущість феноменологічного методу для канонічної психології, схематично подає структуру канону, більш-менш детально визначає та описує канонічні форми психічного та психічних феноменів (характерологічний, відчуттєвий, сприймання, уяви-фантазії, уваги, волі, життєвого шляху людини, екзистенціалів психічного життя, художнього образу, мудрості, учинку, подвигу, особистості, інтересу, емоцій і почуттів). Як справедливо висновує П. А. М'ясоїд, ідеєю канонічної психології «позначений увесь творчий шлях В. А. Ромения, вона ж його логічно й завершує. Це своєрідний творчий синтез усіх його ідей», саможертовна вчинкова післядія - рефлексивне осмислення пройденого шляху, підведення підсумків власної творчості, де вказана ідея становить об'єднавче осереддя змістовно єдиного категорійного ладу авторської версії постнекласичної психології [7, с. 452-453, 464].

Воднораз нами нещодавно здійснена перша спроба презентувати психологічному товариству методологічну схему відновлення предметного поля канонічної психології, відштовхуючись від грунтовних концептуальних напрацювань В. А. Роменця і реінтерпретаційних версій П. А. М'ясоїда [21].

Виділення не вирішених раніше частин загальної проблеми, яким присвячується стаття. Однак очевидно, що написані майже чверть століття тому В. А. Роменцем тексти $з$ канонічної психології потребують не лише деталізації та конкретизації, адже він сам здебільшого говорить про ідею і постання такого напряму психології, який би не зводив наявне багатство психічних феноменів до чогось простого, елементарного, а навпаки у його форматі вивчалися б узірцеві, найдовершеніші й екзистенційною найбільш повновагомі феномени - канони людського життя. Сутнісно мовиться про виняткову важливість чіткої дисциплінарної побудови курсу канонічної психологї, який має всі підстави бути включеним до навчального плану другого (магістерського) освітнього рівня підготовки професійних психологів. Інакше кажучи, академічного обгрунтування потребують об'єкт і предмет, мета і завдання, методологія і методи, категорії і поняття, принципи і підходи, засоби та інструменти вчинково-канонічного пізнання $i$ витлумачення безкрайого горизонту психодуховних процесів, станів, властивостей, тенденцій. Річ у тім, що канонічної досконалості, крім описаних Володимиром Роменцем форм психічного і психічних феноменів, можуть набувати не лише незліченні більш-менш прості психічні утворення (ставлення, установка, потяг, хвилювання, потреба, відреагування, ідеація тощо), а й складноструктуровані (бажання, мотивація, інтенція, депресія, ностальгія, копінг, індивідуальність, конфлікт, психоемоційний клімат, любов, мовлення, гра, вчинок та ін.). Вочевидь у канонічному тлумаченні мають бути охарактеризовані не тільки особистість та інтерес, а ще й переживання, інтелектуальність, подієвість, духовність, самосвідомість, Я-концепція, екзистенційність, психічний світ людини, соцієтальна психіка, психокультура особи, групи, етносу, миследіяльність, рефлексивність, мислевчинення, життя свідомості і т. ін. Водночас у найближчому майбутньому хотілося б, щоб були також започатковані, крім інваріанту емоцій і почуттів, такі напрямки канонічної психології: людини як суб'єкта життєдіяльності, іiі вікового (типологічного) та індивідуального розвитку, а також (окремо) фізичного, розумового, соціального, морального розвитку, онтогенезу особистості, життєвого і творчого шляху людини, іiі загальних, спеціальних і професійних творчих здібностей, компетентної праці (діяльності), діалогічної міжособистісної взаємодії, інно- 
ваційно-психологічного клімату організацій, відповідального вчинку особи, іiі ігрового повсякдення, ціннісно-смислової активності особистості, її самопізнання і самотворення.

Формулювання цілей статті (постановка завдання). Зважаючи на окреслений проблемогенний контекст авторського визначення В. А. Роменцем предмета, методів, завдань і постулатів канонічної психології, з одного боку, й нагальної потреби детальної дисциплінарної організації здобутого ним під завісу XX століття оригінального психологічного знання - 3 іншого, метою цього дослідження $є$ здійснення першого кроку в напрямку миследіяльнісного відновлення й імовірного збагачення даної сфери знання проведення методологічної реконструкиї предметного поля канонічної психології як надважливого сегмента чи вектора розвитку теоретичної психологї̈ з допомогою задіяння новітнього методологічного інструментарію, що в останні десятиліття розробляється нашою науковою школою (див. [26; 27]).

Реконструкція - це, як відомо, здебільшого докорінна перебудова або відновлення чого-небудь за наявними уявленнями-описами чи вченням. У цьому значеннєвому контексті мета конкретизується у таких цілях дослідження:

a) аргументувати вибір циклічно-вчинкового підходу як найбільш адекватного методологічного інструменту реконструкції предметного поля канонічної психології, котра у досвіді пізнавальної творчості В. А. Роменця являє собою результативну парадигмально-дослідницьку програму переходу науковців від XX до XXI століття у психологічному думанні;

б) обгрунтувати особливе місце і виняткове значення у розвитку психологічної науки як важливого складника культури і водночас у системі базових теоретичних дисциплін, де вона відіграє об'єднувальну роль, синтезуючи у знятому вигляді канонічно відфільтровані раціогуманітарні знання;

в) деталізувати чотириіпостасну логічну структуру психологічного канону, використавши інтерпретаційний ресурс учинкової методологічної схеми пізнання В. А. Роменця;

г) узасаднити чотириіпостасну побудову предметного поля канонічної психології як головного напряму розвитку теоретичної психології майбутнього, а також домогтися логіко-змістового визначення кожного сегмента упредметнення за принципом взаємодоповнення.

\section{них наукових результатів. \\ Виклад основного матеріалу дослідження 3 повним обгрунтуванням отрима-}

Циклічно-вчинковий підхід як багатомодульний інструмент рефлексивного методологування. Отож, перш ніж розпочати це дослідження, для нас було очевидно, що всі наявні засоби метатеоретичного аналізу в соціогуманітаристиці або малоефективні, або взагалі недієві чи неадекватні складності предмета психологічного пізнання. Тому перше завдання було пов'язане 3 аргументованим вибором новітнього, якісно складнішого i водночас більш продуктивного, методологічного інструментарію, який би, утримуючи мультифункціональні засоби саморефлексії і метатеоретизування, дозволив розібратися в інваріантній архітектоніці предметного поля як канонічної психології, так і теоретичної психології.

Таким багатомодульним інструментом для нас став авторський циклічно-вчинковий nidxid, що фундується на засадах учинкового підходу В. А. Роменця [8; 9; 10-13], містить взаємозбалансовану єдність чотирьох принципів (учинковості, метасистемності, циклічності, синергійності), шість закономірностей і низку похідних нормативів здійснення рефлексивної миследіяльності [24; 27] та упродовж останніх 15-ти років зреалізовується у рамках створюваної чинною науковою школою вітакультурної методологї [26]. Головне, що цей підхід виявив свою виняткову евристичність при розробці нами і представниками школи моделей: а) повного функціонального кола інноваційного освітнього метапроцесу як довершеної модульно-розвивальної взаємодії працівників і здобувачів відповідного рівня освіти [25, с. 21-27], б) повного парадигмального циклу колективної пізнавальної творчості у сфері науки [24], в) психодидактичного проектування змісту і структури навчаль- 
но-методичних комплексів для ЗВО [17], г) комплексної психодидактичної експертизи модульно-розвивальних підручників для середньої і вищої школи [18], д) повноцінної інноваційної діяльності в освітній сфері суспільства [15], е) циклічно-вчинкової буттєвості гри як онтофеноменальної даності $[28 ; 30], \epsilon)$ циклічно-вчинкової організації і взаємодоповнення концепції внутрішньої єдності логіки доведення і спростування та методології раціональних дослідницьких програм у науковій творчості Імре Лакатоша [16].

Канонічна психологія як діалектичний синтез-підсумок розвитку теоретичних дисциплін психологічної науки. Основна вимога другого завдання дослідження полягала в тому, щоб обгрунтувати особливе місце та виняткову роль канонічної і теоретичної дисциплін у широкому річищі розвитку сучасної психологічної науки. Певним аналогом тут може бути створена у 2013 році нами спільно із С. К. Шандруком мислесхема, що визначає місце і метастатус теоретичної сочіології як базової інтегральної наукової дисципліни серед інших (зокрема й соціальної філософії) галузей соціологічного знання, що мають явно виражене теоретичне спрямування й у взаємодоповненні означують й конституюють предметну сферу сучасної соціології [29, с. 63]. Авторська версія обгрунтування предметних інваріантів базових теоретичних дисциплін психології, а також визначення предметного ядра, виняткового місця й епістемної важливості власне теоретичної i канонічної психологій, послуговуючись відомою інтерпретацією принципу квінтетності (формула: 3+1=1), що характеризує процеси актуалізації апріорного пізнання [19, с. 193], $\epsilon$ такою:

1 - історія всесвітньої психології у визначенні та обгрунтуванні В. А. Роменця;

2 - загальна психологія у її класичному і посткласичному варіантах (С. Л. Рубінштейн, Г. С. Костюк, В. П. Москалець, П. А. М'ясоїд та ін.);

3 - психологічні теорії окремих психічних феноменів - установки, ставлення, несвідомого, мотивації, переживання, гри, учіння,діяльності, спілкування, особистості, вчинку та ін.;

4 - канонічна психологія, ідея якої на завершальному етапі творчого шляху обгрунтована В.А. Роменцем;

5 - теоретична психологія.

Річ у тім, що історія всесвітньої психології (у концепції і самоздійсненні В. А. Роменця [13]), загальна психологія і структурно та функціонально повноцінні психологічні теорії (здібностей і характеру, поведінки і діяльності, особистості та індивідуальності, самосвідомості і Я-концепції та ін.) становлять триєдиний базисний зміст теоретичного каркасу психології, що у знятому синтетичному вигляді унаявлений у витоках, ідеях, принципах і постулатах канонічної психології як учинкового переходу в психологічному думанні, фундованому на синтезі індивідуального і всезагального, повноти існування психічного у його онтологічній вичерпності, феноменологічній цілісності і всеможливих епістемних формоутвореннях. I далі, в сукупній четвертинності у саморефлексивних процедурах проникливого методологічного мислення все здобуте $\epsilon$ тим тотально ідеалізованим, свідомісним матеріалом, із якого постають новоявлені метатеоретичні організованості і в сукупному вимірі-знятті - увесь світ теоретичної психологіï. Остання охоплює ці базові змістові материки у знятому, реконструйованому, сутнісному вигляді й синтезує та універсалізує їх у надбудовну епістемну цілісність, символізуючи своєрідні чи то «золоті куполи», чи то «зіяючі висоти» психологічної науки - методологічні знання про наукове пізнання, іiі ключові проблеми, пояснювальні принципи і категорійний лад. Отож теоретична психологія знівельовує раціогуманітарні знання про психічні процеси, стани, властивості і тенденції й водночас зберігає їх у сутнісному трансформуванні на метарівні самоздійснення методологічно зрілої діяльності теоретичної думки (див. детально [23]).

Те, що історія всесвітньої психології (IВП) є однією з базових теоретичних дисциплін, не викликає сумніву, тим більше, якщо взяти до уваги детальне витлумачення В. А. Роменцем (1990) єдності предмета і принципів становлення історико-психологічного знання для побудови IВП. Вже у вступі докторської дисертації він пише: «ІВП $є$ важким і 
водночас величним шляхом пошуку закономірностей, які керують людською природою, стає знаряддям самопізнання науки. Відкриваються горизонти для постановки цілей визначення шляхів іiі руху-поступу вперед. I чи не найголовніше, що IBП не є пасивним придатком до теоретичної психології, становить, образно кажучи, живу плоть і кров іiі, використовуючи досягнення історичної психології. Отож психологія як наука збагачує своєю історією суперечливу систему знань. Завдяки історичному плюралізму своїх ідей оберігає себе від нав'язливого догматизму і тим упевненіше здійснює й реалізує свій творчий порив» [13, с. 35-36]. Загалом предметний горизонт теоретичних пошукувань IВП доволі панорамний: це й «еволюція, розвиток, формування психологічних знань», і форми їх виражання-уприсутнення «у фольклорі, мистецтві, релігії (теологіï), праві, медицині, філософії, в інших природничих та суспільних науках», й осмислення проблеми людської психіки і людини загалом як власне наукової у її органічному поєднанні з різними формами особистої творчості, і багатоманітні культурні витоки, креативне коріння психологічних ідей, i «перетворення самого предмета психології у процесі ії̈ розвитку» в контексті «поступального тлумачення природи психічного та його місця у світі», й аналіз учинку як логічного осереддя історії психології, передусім рефлексія історико-психологічного зрушення акцентів у вчинковому канонічному осередку та ін. [Там само, с. 35-36].

Чотириіпостасна логічна структура психологічного канону в концепції В. А. Роменця. В. А. Роменець через кілька років творчих пошуків розвиває свою думку в розрізі виняткової значущості метатеоретизування в еволюції психологічного знання, чітко усвідомлюючи, що підсумок історії психології на завершення XX століття сутнісно пов'язаний зі створенням такої теорії, яка б «умішувала в собі всі визначні теорії, що виникли в історико-психологічному русі. Нова теорія не тільки не заперечує у критичному запалі теорії попередні, а надає їм справжнього історичного смислу пізнання. Кожна з них посідає своє місце в загальному потоці психологічного знання, і разом вони виконують велику симфонію, присвячену осмисленню людського буття» [12, с. 884]. Воднораз цей визнаний достойник української нації контурно окреслює обов'язковість етапу канонізації теоретичних уявлень-систем, завдяки якій вони «стають справжніми творами людського духу». Про це він пише так: «...можна стверджувати, що історичний рух психологічної думки відбувається через автономізацію теоретичних позицій, їх протиставлення для чіткого самовизначення, а далі - через їх канонізацію. Кожна психологічна теорія або напрям мають пройти ці стадії, які вже висвітлюють великий канон. I саме канонічна психологія має вміщувати у своїй безмежній і разом з тим чіткій формі все багатство творчих пошуків у психологічній теорії загалом» [Там само, с. 885].

Отож канонізація в недалекому майбутньому, на наш погляд, становитиме не лише засадничий смисл-мотив людської творчості, а й буде обгрунтована як вкрай важлива логіко-методологічна процедура метатеоретизування, котра, поруч із процедурами конструювання, зняття і конфігурування, має посісти важливе місце серед новітніх мислевчинкових засобів саморефлексії психологічної науки. Звісно, це потребує окремих досліджень. Наразі зауважимо, що В. А. Роменець чітко вказує на чотириіпостасний структурно-функціональний цикл-вимір будь-якого логічно зрілого психологічного канону:

а - ситуаційний вимір постання канону відпочатковується від емпіричного (того, що підлягає спогляданню), унаявленого чи сприйнятого як загальне, котре «є лише дотик суб'єкта до дійсності, зіткнення з нею», що засвідчує запитання «Що це таке?» Це його емпірична зустріч зі світом у його ситуаційній динаміці змін, яка завершується вирішальним узагальненням; відтак «канон ніби блукає по світу і шукає себе і спочатку [знаходить] в іншому», осягає цю посутню невідповідність, «тому прагне виділити себе із усього, виокремити себе як індивідуальність, заперечити свою загубленість в іншому, протиставити себе іншому»;

б - мотиваційний вимір утвердження канону характеризує спектр його якісних перетворень, що описуються такими визначеннями, як індивідуальне, неповторне, оригінальне, унікальне, особливе; зокрема первинне наснаження стимулює суб'єкта до 
репродукції, відтворення, і лише $з$ актуалізацій «індивідуальності починається справжнє виділення себе зі світу, усвідомлення своєї неповторності, яке має бути зафіксоване в оригінальності як вищій якості індивідуальності»; мотиваційний шлях розпросторюється «від наївних пошуків несхожості на інших до суттєвих знахідок оригінального», якому притаманне світіння всезагального, причому, «цей шлях є своєрідним лабіринтом ходів, спрямувань, які і утримуються, і водночас заперечуються, щоб відчути всезагальне як субстанціальне»; та канон долає здебільшого примхливе, нестійке або випадкове індивідуальне;

в - діяльнісний вимір учинкового здійснення канону - це актуальний розвиток, змістове наповнення й утотальнення оригінального як субстанційної атрибуції, тобто як незмінного засновку всього існуючого, як установлення справжності, автентичності миследіяльно опрацьованої сутності самій собі, що вказує на досягнення людиною всезагального як вищого рівня буттєвої присутності того чи іншого канону в іï особистісному світі; загалом тільки через вершинно зреалізоване оригінальне уможливлюється досягнення собою найбільшого і найзагальнішого в ній - спектру довершених технологічних канонів; «тому оригінальне виступає найближчим інструментом розкриття канонічного підходу», де одним із засадничих постулатів $є$ вимога (науки і життя) в кожному психічному феномені виявити мислевчинковий поступ канону;

Г - післядіяльний вимір повноти й довершеності існування канону становить усе досконале відтворення всезагального: крізь безліч еталонних образів як суб'єктивованих чи й об'єктивованих свідоцтв життя людської свідомості не тільки «світиться сама безконечність» (Г. В. Ф. Гегель), а й канонізуються у рефлексивному випромінюванні психічні феномени-події і «стають справжніми творами людського духу» (В. А. Роменець); у підсумковому самозвітуванні «людина переступає досконалий образ, щоб відчути у самій чуттєвості вище захоплення»; канон - не абстракція, а «жива досконалість», «не просто ідеалізований образ психічного життя, це сама діалектика наявного та очікуваного, де драматично переплітаються минуле, сучасне, майбутнє, нарешті це рушійна сила та взірець психологічного знання, яке розгортається на грунті вчинкового осередку психологічної системи». «У цьому останньому вимірі канонічною буде така психологія, - пише Володимир Роменець, - що в кожному психологічному феномені шукатиме тенденцію руху саме до канону», який являє собою не абстракцію, а виражає «живу досконалість», точніше, «він і є самим досконалим образом». I «це вимога не теоретичної психології, а вимога життя». Звідси вповні зрозуміло, чому «ідея канону є душею поступального руху» вчинкової самоорганізації та систематизації психологічних знань в неперервному історико-психологічному дискурсі. Тому й «смисл канонічної психології, за визначенням академіка-творця нової теоретичної системи, полягає в тому, що ідея канону як животворча сила сприяє рухові осередку та поступальному історичному рухові теорії психології...» [12, с. 899-900].

Логіко-змістове визначення головних сегментів упредметнення канонічної психології як теоретичної системи. Канонічна психологія, як суто авторське відкриття видатного українського філософа та історика психології Володимира Роменця [11; 12], під завісу XX століття виникає як своєрідна світоглядна постава чи метапозиція бачення та осягнення психічного. Ї̈і передісторію, як зазначає сам фундатор нової течії теоретизування, становлять провідні напрями еволюції психологічного знання - емпіричний, раціональний, феноменологічний, екзистенційний, які за логікою поділу і розвитку утворюють те змістовно багате підгрунтя, на яке спирається ця, зорієнтована на взірцеві психодуховні феномени і подієву розгортку визначення сенсу людського життя, психологія. А це означає, що, з одного боку, «кожний психічний феномен слід тлумачити, враховуючи структуру вчинку - його ситуативний, мотиваційний, дійовий і післядійовий (рефлексія) моменти» [11, с. 605], з іншого - розуміти канон як «рушійну силу та взірець психологічного знання, яке розгортається на грунті вчинкового осередку психологічної системи», і не тільки як ідеалізовану схему цього знання, а й те, як «він світиться у пошуках, у 
відкиданні неістинного, у ствердженні самого руху знання, у заміщенні його реальними формами...» [12, с. 881-882].

У цій ситуації методологування нам важливо підкреслити, що поліаспектний предмет канонічної психології сукупно входить у предметне поле теоретичної психології, або, образно кажучи, є іiі найбільшим, поки що мізерно освоєним науковою думкою, материком. Будь-яка подія у психічному житті людини - це справді «завершальний етап самого вчинку, коли рефлексія констатує непересічну його значущість». Іншими словами, мовиться про постійне метапозиціювання під час методологічно виваженої теоретичної діяльності у роботі зі взірцевими зорганізованостями вчинення й відтак із канонічною архітектонікою сенсовизначених і вчинково спричинених подій. Це вимагає надрефлексивності, або створення «підсумкового поля рефлексії» (у термінології М. С. Гусельцевої [2]), коли має місце «рефлексія рефлексії, яка виходить за межі суб'єктивності і показує втручання вчинкової акції в саму об'єктивну дійсність. Разом із переображенням людини відбувається переображення дійсності - уявне і реальне...» [11, с. 605].

Яскравими прикладами-творами метатеоретичного позиціювання-аналізу є теорія соиіального устрою вільного народу відомого австрійського економіста-психолога Фрідріха Гаєка (1899-1992) [39], філософська конщепція теоретичної психологї сучасного американського мислителя Томаса Тео [40], а також новаторський дисциплінарний напрям розвитку гуманітарного пізнання - аксіопсихологія особистості, фундатором якого є відома українська сподвижниця Зіновія Карпенко [3-5], і теорія інноваційно-психологічного клімату організачій української дослідниці Оксани Фурман [31-34]. Зокрема перший упродовж сорока років, починаючи із 1952, поєднував епістемологію та індивідуалізм у річищі ліберальної філософії, де своєрідним ключем до розуміння можливостей та обмежень індивідів у просторі суспільного життя є соціальний (і вужче політичний) порядок як засадничий принцип організації людського знання, дотримання вимог якого сьогодні збагачує як економічну і соціальну теорії, так і теоретичну психологію (скажімо, евристичними тут видаються концепти «відчуття порядку» (The Sensory Order's), «міраж соціальної справедливості» та ін.). Другий висвітлює фундаментальні філософські проблеми теоретичної психології як наукової дисципліни і професійної дослідницької діяльності та пропонує їх можливі розв'язки шляхом взаємодоповнення традиційних ракурсів філософського розмірковування - онтологічного, епістемологічного, етичного та естетичного. У підсумку він доходить двох найважливіших висновків: для того щоб покращити психологію як академічну дисципліну і як спосіб людського практикування, потрібно відновити розділ методологічно компетентного психологічного аналізу, що уможливлює погляд дослідника чи практика за межі його індивідуальної спроможності чи навіть його власного досвіду; лише конструктивне задіяння продуктивних розв'язків указаних філософських проблем дасть змогу психології уникнути ії звичних підводних каменів і продовжити бути силою, що здатна чинити опір усьому тому, що обмежує дію добра.

Стосовно метатеоретичних систем вищеназваних українських дослідниць зауважимо головне: за четвертинним критерієм повнота висвітлення надскладного - різноманітного, мінливого, рекурсивного - предмета пізнання (ціннісно-смислової сфери особистості та інноваційно-психологічного клімату організацій відповідно), тобто за його буттєвою вичерпністю, ідеалізованою багатопараметричністю цілісного функціонування, феноменальною вираженістю і за архетипно-взірцевою оргсхемою вчинкової подієвості, вони не лише психозмістовно й результативно перевершують згадані дослідження Ф. Гаєка і Т. Тео, а й слугують для інших науковців своєрідним філософсько-психологічним каноном компетентного гуманітарного пізнання. І справді, аксіологічна теорія особистості 3.С. Карпенко $\epsilon$ переконливим аргументом вдало здійсненого зняття-конфігурування у високому саморефлексивному злеті абстрактно-синтетичної діяльності в рамках актуальної проблематики теоретичної психології, що здійснювана упродовж останніх тридцяти років на передньому краї постнекласичних парадигмальних досліджень у напрямку багатоаспектного 
висвітлення аксіологічного персоногенезу. Інваріантний набір конфігураторів у досвіді метатеоретизування Зіновії Степанівни становлять ті авторські моделі, що зреалізовують вимоги принципу інтегральної суб'єктності (передусім їі спектрально-порівневого функціонування як відносного суб'єкта, моно-, полі-, мета- й абсолютного суб'єкта), який процесно та результативно уможливив здійснення аксіологічної реінтерпретації культурно зорієнтованих, психодинамічних, феноменологічних та психотерапевтичних аспектівпроекцій імовірнісного свідомісного унаявлення ціннісно-смислового онтогенезу.

Певний учинковий канон ефективного застосування логіко-методологічної процедури конфігурування і побудови на цій основі методологічної план-карти дослідження такого надскладного об'єкта, як інноваційно-психологічний клімат загальноосвітнього закладу та низки його параметрично рубрикованих упредметнень демонструє у рамках предметного поля теоретичної психології О. Є. Фурман (Гуменюк). Зокрема в результаті конфігурування дослідницею, з одного боку, чітко розмежовані чотири предмети вивчення (психологічний уплив, полімотивація, освітнє спілкування, позитивно-гармонійна Я-концепція) й логічно узгоджене співвідношення їх складників і параметрів, з іншого отримані синтетичні знання метатеоретичного рівня ідеальної буттєвості, що, будучи зведені в єдине складноструктуроване епістемне мереживо, уможливили побудову багатосторонньої психологічної картини життя інноваційно-психологічного клімату як масштабного об'єкта міждисциплінарного вивчення.

Вищезазначене дає змогу ескізно окреслити чотирисегментну побудову предметного поля канонічної психології як магістрального напряму розвитку теоретичної психології майбутнього:

1 - філософсько-психологічний напрям розвитку людинознавства, що в авторському витлумаченні В.А. Роменця визначає сенс, зміст і спосіб людського життя в наступності відповідних учинків-канонів людини як суб'єкта повсякдення та особистості в контексті виконання нею соціальних ролей і різних діяльностей та їх перманентно результатуючому подієвому здійсненні, коли світоглядні принципи і психологічні закономірності осмислюються на рівні буттєвого канону і в його межах отримують власну феноменальну довершеність і своєрідність; у цьому метатеоретичному вимірі оберненою стороною і водночас своєрідним продовженням канонічної психології є психософія вчинку як методологія пізнання джерел і сутності людського буття у взірцевих практиках вчинкового діяння і досягнення натхненною особистістю життєвої мудрості;

2 - науково-світоглядний «перехід від XX до XXI століття у психологічному думанні» (В.А. Роменець), що спричиняє постання психології, яка своїми метатеоретичними побудовами і саморефлексуванням дослідницьких засобів «здолала однобічність попередніх психологій і вказала на синтез індивідуального і всезагального», неповторного та універсального у буттєвій мозаїці людського життя, тобто утвердження такої психології, яка інтерпретує психосферу особи, групи, загалу як «коловерть мислительного (теоретичного) і реального (практичного) осягнення світу, зокрема світу людської психіки», і яка «через індивідуалізм, неповторність дає людині можливість рухатися до всезагального, відчути безконечне духовне багатство, в якому взаємодіють і взаємозбагачуються всі індивідуальності» [12, с. 880, 881];

3 - метасистема фундаментальних (себто основоположних стосовно засновків i сутності людського буття) психологічних знань, що збагачена у пізнавальній творчості В.А. Роменця і представників його наукової школи філософськими, історичними, міфологічними, літературно-мистецькими i власне методологічними інсайтами-розвідками й охоплює як інтеграцію взірцевих психічних феноменів й еталонно (архетипно, онтопсихічно, узаконено тощо) здійснених учинків-подій, так і ті психологічні закономірності, що досягають «рівня життєвого, буттєвого канону і в його межах отримують власну своєрідність»; інакше кажучи, мовиться про таке кількаразово відрефлексоване метазнання, котре зінтегровує кілька площин людського буття у його свідомісному вимірі - індивідуальному, соціальному, історичному і самоусвідомлювальному, де життєактивність 
особи виявляє себе найповнішим чином, будучи згорнута у єдиний феноменологічний $к а н о н$, взятий у його буттєвій невичерпності та ідеалізаційній багатоманітності;

4 - головна течія розвитку теоретичної психології інтелектуальними засобами

iї саморефлексії у кількох взаємопов'язаних напрямках: вчинкового осередку психологічної метасистеми як функціонального набору концентричних кіл - від актуалізації, ідеологічного спонукання і переображення об'єкта вчинку до смисложиттєвого вчинення-покликаня й до реалізації його у безперервному вчинковому процесі-діянні; канону як рушійної сили і взірця психологічного знання, як «ідеалізованого образу психічного життя» і водночас як «діалектики наявного та очікуваного, того сучасного, в якому драматично переплітаються минуле і майбутнє» [12, с. 909]; реалізащії «у вчинку буттєвих визначень людської особистості», що спонукає усуб'єктнений вихід вчинкового осередку як «живого ядра психіки» за свої межі - у творчі інсайти «переходу логіки цього осередку в саму психологічну систему» [Там само, с. 882]; нарешті подієво-свідоцьке підтвердження плідності саморефлексивних зусиль психологів-дослідників стосовно канонічної повноти циклу виникнення, розгортання, вищого усистемнення вчинкового осередку оновленого теоретичного канону психології, що виходить за свої дисциплінарні межі та повертається до самого себе.

Вказаний напрям розвитку теоретичної психології - це сьогодні універсальний й абсолютно достатній у своїх можливостях орієнтир-засіб чи навіть світогляд, яким, на переконання академіка Володимира Роменця, психософія вчинку $\epsilon$ «цілісна система уявлень про закономірності становлення та виявлення у вчинковому діянні сутності індивідуального людського буття». Тому вона являє собою «достеменну психологію та філософію буттєвої мудрості», «своєрідну функціональну модель індивідуального буття, яка постає системою конкретних знань про його сутність та про те, яким чином, через застосування яких засобів можливо досягти певного рівня володіння реально-вітальними технологіями самозабезпечення ефективності розгортання життєдіяльності людини...», «шлях до мудрості, шлях до того, як бути натхненним, спрямованим до світу в якості активного, дійового партнера», «певний універсальний алгоритм буттєвого руху людини до вчинку: від етапу до етапу, від потенції можливості до реальності дійсного звершення, від первинного рівня до вершинного утвердження свого буттєвого статусу Людини-творця...» [12, с. 754-755, 757]. У кількох методологічних розвідках [8, с. 191-205; 26, с. 779-788; 9, с. 108116; 19, с. 313-323] нами доведено, що Володимир Роменець «не тільки самодостатній, потужний, непересічний теоретик-гуманіст, а й, щонайважливіше, яскравий, послідовний і продуктивний методолог, який своїм самопізнанням освоїв новий шлях розвитку наук про людину - вчинково-канонічну схему організації гуманітарного пізнання як рефлексивну миследіяльність особливого - психософійного - типу». I дійсно, канонічна психологія, охоплюючи метатеоретизуванням філософські і психологічні студії-дискурси, являє собою «синтез усіх ідей В. А. Роменця, підсумок усіх його кроків» (П. А. М'ясоїд) і водночас становить довершений теоретичний канон цілісного гуманітарного знання.

Насамкінець сформуємо цілком гіпотетичне визначення: канонічна психологія це постнекласична наука нового інтегрального (міждисциплінарного) типу, яка має історико-філософсько-психологічне об'єктне спрямування $і$ предметно синтезує всеможливі культурно-гуманістичні узмістовлення й епістемні форми-свідоцтва, вивчає людину як твория і носія вчинкового способу перебування у світі й обтрунтовує ї̈ шлях (зокрема принциии, підходи, методи, способи, засоби) до екзистенційної повноти $і$ свідомісної вичерпності осмисленого життя [14; 20; 22].

Перспективи дослідження. За логікою прийнятого метатеоретизування настуnним завданням, яке постає перед нами, є здійснити аргументований вибір методологічних засобів пізнання задля впорядкування багатоаспектної картини упредметнення теоретичної психології з подальшою можливістю виходу як на ідею вчинку метатеоретизування, так і на концепт теоретичного канону в психології. I це тим більше виправдано, що провідною тенденцією в обгрунтуванні психології, за аналітикою В. А. Роменця, $\epsilon$ 
«логічний взаємоперехід об'єктивного і суб'єктивного як процесна хвиля становлення, визначення й формування психічного у зв'язку з учинковим осередком» і далі - рефлексія історико-психологічного зрушення акцентів у цьому осередку із ситуації на мотивацію, від неї на дію і післядію в розумінні та витлумаченні поведінки людини, в дослідженні психіки в цілому, що вперше уможливлює «культурологічну періодизацію IВП як базис для історико-психологічної орієнтації» всього гуманітарного пізнання [13, с. 37-38]. У нашому випадку надзавдання буде полягати в рефлексивному визначенні циклічновчинкової організації засадничих складників-сегментів предметного поля теоретичної психології, їх досконалого логіко-змістового наповнення та з інтенцією досягнути канон власного метатеоретизування.

\section{ВИСНОВКИ}

1. Канонічна психологія - одне із вершинних культурних досягнень-здобутків натхненного людського духу, який отримав реальне уособлення на підсумковому етапі творчого шляху видатного українського психолога-мислителя Володимира Роменця. Як науково-філософський проект перебудови всієї системи психологічного думання, що покликаний здійснити сталий культурно-гуманістичний, світоглядний перехід від ХХ до XXI століття, вона становить продукт усіх раніше висловлених та обгрунтованих цим достойником української нації ідей, концептів, постулатів, підходів, методологем і $\epsilon$ логічним завершенням його винятково оригінальних пошуків. Об'єктом канонічної психології є людина, для якої основоположним способом буття є вчинок і вчинення: перший уможливлює достеменне пізнання і перетворення нею світу і самої себе, дає змогу максимально розвивати свої сутнісні сили (здібності) та реалізувати своє високе признання як свідомої одухотвореної особи, друге характеризує повноту їі активної присутності у світі і цього останнього у психічному засвіті як повновагомого суб'єкта життєдіяльності й одночасно як натхненної непересічної особистості, котра здатна піднятися до взірцевих, канонічних вершин самопізнання і самотворення.

2. Відносно предмета канонічної психології В. А. Роменець і П. А. М'ясоїд неодноразово вказувати (звісно, в дещо відмінних формулюваннях), що таким предметом $\epsilon$ або життя, взяте у процесі розвитку як реальне вмістилище всіх психічних процесів - від найпростіших до найскладніших (стани, переживання, особистісний смисл, самосвідомість тощо); або «людина, котра йде історичним шляхом самопізнання й переображення», нарощуючи розгортання «вчинкових спіралей» і піднімаючись «сходинками буття»; або взірцеві (канонічні) явища у їх подієвій мозаїці та наповненій сенсом людського існування буттєвій повноті й достатній феноменальній вираженості, що охоплюють індивідуальний, соціальний, історичний формати активності і внутрішній план самоактивності особи, які оприявнюються у таких базових формах-здатностях присутності їі у світі, як поведінка (ситуаційна домінанта людської екзистенції), спілкування (переважання мотиваційних джерел і тенденцій), діяльність (вактуальнення дієво-перетворювального впливу особи на світ, який відтепер ознаменований учинковим способом іiі буття), вчинок (післядіяльне, інструментально дореалізовуване й подієво довершуване розкриття особою світу як способу власної буттєвї присутності, набуття цим світом визначеностей, ситуаційна зміна життєвих умов й одночасно самовиявлення іï психічного, передусім особистісного, засвіту). У цьому проблемному контексті творчого діалогу учнів, наступників і конструктивно налаштованих прибічників 3 академіком В. А. Роменцем очевидно, що $є$ підстави говорити про багатосегментне й складно рубриковане предметне поле канонічної психології, що потребує мислерефлексивного опрацювання як новозастосованої українським любомудром методологічної оптики філософсько-психологічного дослідження, так і логічно аргументованого розмежування відповідних сегментів чи інваріантів упредметнення зазначеної версії утвердження постнекласичного психологічного дискурсу.

3. Канонічна психологія - це також ще й відмінна від усіх існуючих у психологічній науці дослідницько-світоглядна стратегія пізнання джерел, сутності і безкрайої феноме- 
нології людського способу екзистенційно повного життя в реальному світі з орієнтирами на суб'єктність і вчинково-подієву продуктивність змісту буття. Заперечуючи неканонічні системи психології (у тому числі психоаналіз і гуманістичну течію), загальною вадою яких $є$ намагання звести надскладне психічне і все багатство його феноменальних проявів до нижчого, простого, елементарного, В. А. Роменець обстоює й утілює у власній пізнавальній творчості альтернативну методологічну позицію - вивчає психічні явища у їх якомога більш довершеній цілісності, у канонічних формах, буттєвій повноті, феноменальній викінченості й у неподільному зв'язку і збалансуванні з іншими психологічними канонами. Воднораз сьогодні існує нагальна потреба не тільки деталізувати і конкретизувати концепти, принципи і постулати канонічної психології, а й надати їй чіткої дисциплінарної побудови, що уможливило б включення цього змістовно збагаченого академічного курсу до навчальних планів другого (магістерського) освітнього рівня підготовки професійних психологів.

4. Для збагаченого відновлення епістемної сфери канонічної психології потрібно зреалізувати щонайменше чотири методологічних настановлення: а) миследіяльно розробляти iї як новітній інтеграційний напрям розвитку людинознавства й наук про свідомість, як комплекну дослідницьку програму культурно-гуманістичного спрямування й одночасно як надважливий сегмент чи вектор становлення сучасної теоретичної психології, предметне поле якої також пов'язане із самопізнанням і саморефлексією принципів і закономірностей психологічного пізнання, базових проблем, основоположень і підходів, системи понять і категорійного ладу психологічної науки [23]; б) мислекомунікаційно освоювати основні умови зреалізування як методологічної процедури типологізації, так i найважливіших характеристик типологічного методу [19] стосовно багатосегментного предметного поля канонічної психології, виділивши окремі таксони, тобто групи певним чином пов'язаних категорій, і побудувавши у підсумку проведеного вчинково-типологічного дослідження іiі категорійну матрицю; в) мислевчинково опрацьовувати авторський циклічно-вчинковий підхід як адекватний багатомодульний інструмент рефлексивного методологування, що уможливлює на засадах поєднання переваг учинкового і типологічного підходів виокремлення четвертинного оптимуму головних сегментів упредметнення канонічної психології з перспективою отримання метасистемної єдності знань психософійних, проблемно-дискурсивних, особистісних (явних і неявних), категорійних; г) зважаючи на реконструйовану логічну структуру психологічного канону, обгрунтовану В. А. Роменцем, мислерефлексивно висвітлювати рух-поступ кожного психодуховного феномену до канону як оприявненої у взаємодії людини і світу живої, екзистенційно вичерпної та особистісно зреалізованої досконалості й відтак здійснювати поступове структурно-змістове наповнення канонічної психології як теоретичної метасистеми.

5. Запропонована нами методологічна схема відновлення предметного поля канонічної психології охоплює чотири головних сегменти, у яких знаходить відображення вчинково-канічна структурна логіка поступального розвитку і систематизації фундаментальних психологічних знань. Так, ситуаційний сегмент упредметнення презентує вказану версію психології як постнекласичну, а саме як філософсько-психологічний напрям розвитку сучасного людинознавства, що вивчає сенс, зміст і спосіб людського життя у його взірцево подієвих, канонічно-вчинкових формах, збагачуючись психософією як методологією пізнання джерел і сутності людського буття; мотиваційний - становить проблемнодискурсний за формою миследіяльного напруження і науково-світоглядний за інтенційним горизонтом свідомісних ідеалізацій етап або «перехід від XX до XXI століття у психологічному думанні» (В. А. Роменець), що ознаменований якісно іншою за складністю завдань і за гносеологічною спроможністю психології - тієї, що «здолала однобічність попередніх психологій і вказала на синтез індивідуального і всезагального, неповторного та універсального у буттєвій мозаїці людського повсякдення»; діяльний - являє собою відкриту для значеннєво-смислових конотацій і полісемантичних визначень систему фундаментальних раціогуманітарних знань, які здобуті В. А. Роменцем на різному культурно- 
історичному матеріалі й об'єктивовані ним як відрефлексоване психологічне метазнання стосовно генези, закономірностей і вчинкових канонів людського життя у його буттєвій невичерпності, феноменальній повноті, свідомісний функціональній здатності і довершеній особистісній подієвості; післядіяльний - ковітально втілений як самобутня наукова школа В. А. Роменця (П. А. М'ясоїд, В. О. Татенко, Т. М. Титаренко та ін.), дослідницька програма якої становить одну із головних течій розвитку постнекласично зорієнтованої теоретичної психології з ії інтелектуальними засобами метатеоретичного аналізу, вчинкового принципу, канонічного підходу, категорійного ладу, грунтовної саморефлексії та у центруванні на повноцінності циклу виникнення, розгортання і вищого усистемнення вчинкового осередку теоретичного канону психології, що виходить за свої дисциплінарні межі і повертається в індивідуальних, групових та колективних актах рефлексування до самої себе.

1. Андрущенко, В. П., Михальченко, М. І. (1996). Сучасна соиіальна філософія: курс лекиіий. Київ: вид. Генеза».

2. Гусельцева, М. С. (2017). Методологічна оптика як інструмент пізнання. Психологія і суспільство, 4, 39-55. DOI: https://doi.org/10.35774/pis2017.04.039.

3. Карпенко, 3. С. (2018). Аксіологічна психологї̈ особистості: монографія. (2-е вид., переробл., доповн.). Івано-Франківськ : ДВНЗ «Прикарпатський національний університет імені Василя Стефаника».

4. Карпенко, 3. С. (1998). Аксіопсихологія особистості: монографія. Київ: ТОВ «Міжнародна фінансова агенція».

5. Карпенко, 3. С. (2008). Предмет і метод аксіопсихології особистості. Психологія і суспільство, 1, $36-62$.

6. М'ясоїд, П. А. $(2011,2013)$. Курс загальної психології: підручник: у 2 т. Київ: Алетра.

7. М'ясоїд, П. А. (2016). Психологічне пізнання: історія, логіка, психологія. Київ: Либідь.

8. М’ясоїд, П. А. (Упоряд.), Шатирко, Л. О. (Ред.) (2016). Академік В. А. Роменеиъ: творчість праиі: зб. ст. Київ: Либідь.

9. М'ясоїд, П. А. (Упоряд.), Фурман, А.В. (Ред.) (2012). Психологія вчинку : Шляхами творчості В. А. Ромения: зб. ст. Київ: Либідь.

10. Роменець, В. А. (2007). Історія психології XIX-початку XX століття: навч. посіб. Київ: Либідь.

11. Роменець, В. А. (1995). Постання канонічної психології. Киричук О. В., Роменець В. А. (Заг. ред.). Основи психологіï: підручник, 605-621. Київ: Либідь.

12. Роменець, В. А., Маноха, І. П. (2017). Історія психології ХХ століття: навч. посіб. (3-є вид.). Київ: Либідь.

13. Роменець, В. А. (2013). Предмет і принципи історико-психологічного дослідження. Психологія $i$ суспільство, 2, 6-27.

14. Фурман, А. А. (2017). Психологія смисложиттєвого розвитку особистості: монографія. Тернопіль: ТНЕУ.

15. Фурман, А. В. (2014). Вступ до теорії освітньої діяльності: курс лекцій. (Вид. 2-е). Тернопіль, НДІ МЕВО.

16. Фурман, А. В. (2013). Генеза науки як глобальна дослідницька програма: циклічно-вчинкова перспектива. Психологія і суспільство, 4, 18-36.

17. Фурман, А. В., Гірняк, Г. С., Гірняк, А. Н. (2012). Психодидактика проектування навчальнокнижкових комплексів для студентів ВНЗ: монографія. Тернопіль: ТНЕУ.

18. Фурман, А. В., Гірняк, А. Н. (2009). Психодидактична експертиза модульно-розвивальних підручників: монографія. Тернопіль: ТНЕУ.

THEY.

19. Фурман, А. В. (2016). Ідея i зміст професійного методологування: монографія. Тернопіль:

20. Фурман, А. В. (2018). Метатеоретична мозаїка життя свідомості. Психологія і суспільство, 3-4, 13-50. DOI: https://doi.org/10.35774/pis2018.03.013.

21. Фурман, А.В. (2019). Методологічна схема відновлення предметного поля канонічної психології. Вітакультурний млин, модуль 21, 4-27.

22. Фурман, А. В. (2018). Метатеоретичні концепти пізнання свідомості. Психологія особистості, 9 , 5-11. DOI: https://10.15330/ps.9.1.5-11.

23. Фурман, А. В. (2019). Методологічне обгрунтування предметного поля теоретичної психології. Психологія і суспільство, 3-4, 5-29. $3,72-85$.

24. Фурман, А. В. (2013). Парадигма як предмет методологічної рефлексії. Психологія і суспільство,

25. Фурман, А. В. (2005). Система інноваційної освітньої діяльності модульно-розвивальної школи та ії комплексна експертиза. Психологія і суспільство, 2, 29-75. 
26. Фурман, А. В., Фурман, О. С., Шандрук, С. К., Гірняк, А. Н. та ін. (2019). Вітакультурна методологія: антологія. До 25-річчя наукової школи професора А. В. Фурмана: колективна монографія. Тернопіль: ТНЕУ.

27. Фурман, А. В., Фурман, О. С., Шандрук, С. К., Фурман, А. А. та ін. (2019). Методологія і психологія гуманітарного пізнання: колективна монографія. До 25-річчя наукової школи професора А. В. Фурмана. Тернопіль: ТНЕУ.

28. Фурман, А. В., Шандрук, С. К., (2014). Організащійно-діяльнісні ігри у вищій школі: монографія. Тернопіль: ТНЕУ.

29. Фурман А. В., Шандрук С. К. (2013). Соціема як евристичний концепт загальної соціальної теорії. Психологія і суспільство, 1, 57-74.

30. Фурман, А. В., Шандрук, С. К. (2014). Сутність гри як учинення: монографія. Тернопіль: ТНЕУ.

31. Фурман (Гуменюк), О. С. (2012). Методологія пізнання освітнього вчинку в контексті інноваційно-психологічного клімату. Психологія і суспільство, 1, 47-81.

32. Фурман (Гуменюк), О. Є. (2008). Теорія і методологія інновачійно-психологічного клімату загальноосвітнього закладу: монографія. Ялта-Тернопіль: Підручники і посібники.

33. Фурман, О. С. (2015). Психологічні параметри інноваційно-психологічного клімату загальноосвітнього навчального закладу. (Автореферат доктора психологічних наук). Д3 «Південноукраїнський національний педагогічний університет імені К. Д. Ушинського». Одеса.

34. Фурман, О. С. (2018). Я-концепція як предмет багатоаспектного теоретизування. Психологія $i$ суспільство, 1-2, 38-67. DOI: https://doi.org/10.35774/pis2018.01.038.

35. Щедровицький, Г. П. (2005). Схема миследіяльності - системно-структурна будова, значення i зміст. Психологія і суспільство, 4, 29-39.

36. Петровский, А. В., Ярошевский, М. Г. (2001). Теоретическая психология: уч. пос. Москва: Изд. центр «Академия». РОССПЕН.

37. Щедровицкий, П. Г., Данилова, В. Л. (Ред.) (2010). Георгий Петрович Щедровицкий. Москва:

38. Щедровицкий, П. Г. (1995). Избранные трудыл. Москва: Шк. культ. политики.

39. Hayek, F. A. (2017). The Sensory Order and Othen Writings the Foundations of Theoretical Psychology. University of Chicago Press.

40. Teo, T. (2018). Outline of Theoretical Psychology (Critical Investigations). McMillan.

\section{REFERENCES}

1. Andrushchenko, V. P. \& Mykhalchenko, M. I. (1996). Suchasna sotsialna filosofiia: kurs lektsii [Modern social philosophy: a course of lectures]. Kyiv: «Heneza». (ukr.).

2. Huseltseva, M. S. (2017). Metodolohichna optyka yak instrument piznannia [Methodological optics as a tool of cognition]. Psykholohiya i suspilstvo [Psychology and society], 4, 39-55. (ukr.).

3. Karpenko, Z. S. (2018). Aksiolohichna psykholohiiia osobystosti [Axiological psychology of personality]. Ivano-Frankivsk: DVNZ «Prykarpatskyi natsionalnyi universytet imeni Vasylia Stefanyka». (ukr.).

4. Karpenko, Z. S. (1998). Aksiopsykholohiia osobystosti [Personality axiopsychology]. Kyiv: TOV «Mizhnarodna finansova ahentsiia». (ukr.).

5. Karpenko, Z. S. (2008). Predmet i metod aksiopsykholohii osobystosti [Subject and method of personality axiopsychology]. Psykholohiya i suspilstvo [ Psychology and society], 1, 36-62. (ukr.).

6. Miasoid, P. A. (2011). Kurs do zahalnoi psykholohii [Course in General Psychology]. Vol. 1. Kyiv: Alerta. (ukr.).

7. Miasoid, P. A. (2016). Psykholohichne piznannia: istoriia, lohika, psykholohiia [Psychological knowledge: history, logic, psychology]. Kyiv: Lybid. (ukr.).

8. Miasoid, P. A. \& Shatyrko, L. O. (Eds.). (2016). Akademik V. A. Romenets: tvorchist i pratsi [Akademic V. A. Romenets: creativity and work]. Kyiv: Lybid. (ukr.).

9. Myasoid, P. A. \& Furman, A. V. (Eds.). (2012). Psykholohiia vchynku: Shliakhamy tvorchosti V. A. Romentsia [Psychology act: the way of creativity, of Romenets V. A.]. Kyiv: Lybid. (ukr.).

10. Romenets,V. A. (2007). Istoriya psikhologii XIX-pochanku XX stolittia [History of Psychology XIX early XX century]. Kyiv: Lybid. (ukr.).

11. Romenets,V. A. \& Kyrychuk, O. V. (Eds.). (2006). Osnovy psykholohii [Principles of psychology]. Kyiv: Lybid. (ukr.).

12. Romenets, V. A. \& Manokha, P. I. (2017). Istoriia psykholohii XX stolittia [History of psychology of the twentieth century]. Kyiv: Lybid. (ukr.).

13. Romenets, V. A. (2013). Predmet i pryntsypy istoryko-psykholohichnoho doslidzhennia. Psykholohiya $i$ suspilstvo [Psychology and society], 2, 6-27. (ukr.).

14. Furman, A. A. (2017). Psykholohiia smylozhyttievoho rozvytku osobystosti [Psychology of the meaning-life personality development]. Ternopil: TNEU. (ukr.).

15. Furman, A. V. (2014). Vstup do teorii osvitnoi diialnosti: kurs lektsii [Introduction to the theory of educational activity: a course of lectures]. Ternopil. (ukr.). 
16. Furman, A. V. (2013). Geneza nauky yak hlobalna doslidnytska prohrama: tsyklichno-vchynkova perspektyva [The genesis of science as a global research program: a cyclical-actual perspective]. Psykholohiya $i$ suspilstvo [Psychology and society], 4, 18-36. (ukr.).

17. Furman, A. V. \& Hirniak, H. S. \& Hirniak, A. N. (2012). Psykhodiahnostyka proektuvannia navchalnoknyzhkovykh kompleksiv dlia studentiv VNZ [Psychodiagnostics of designing educational and book complexes for university students]. Ternopil: TNEU. (ukr.).

18. Furman, A. V. \& Hirniak, A. N. (2009). Psykhodydaktychna ekspertyza modulno-rozvyvalnykh pidruchnykiv [Psychodidactic examination of module-development textbooks]. Ternopil: TNEU. (ukr.).

19. Furman, A. V. (2016). Ideia i zmist profesiinoho metodolohuvannia [The idea and content of professional methodologization]. Ternopil: TNEU. (ukr.).

20. Furman, A. V. (2018). Metateoretychna mozaika zhyttia svidomosti [A meta-theoretical mosaic of the life of consciousness]. Psykholohiia i suspilstvo [Psychology and society], 3-4, 13-50. (ukr.).

21. Furman, A. V. (2019). Metodolohichna skhema vidnovlennia predmetnoho polia kanonichnoi psykholohii [Methodological scheme of restoration of the subject field of canonical psychology]. Vitakulturnyi mlyn [Viticultural mill], 21, 4-27. (ukr.).

22. Furman, A. V. (2018). Metateoretychni kontsepty piznannia svidomosti [Metatheoretical concepts of cognition of consciousness]. Psykholohiia osobystosti [Psychology of personality], 1 (9), 5-11. (ukr.).

23. Furman, A. V. (2019). Metodolohichne obgruntuvannia predmetnoho polia teoretychnoi psykholohii [Methodological substantiation of the subject field of theoretical psychology]. Psykholohiia i suspilstvo [Psychology and society], 3-4, 5-29. (ukr.).

24. Furman, A. V. (2013). Paradyhma yak predmet metodolohichnoi refleksii [Paradigm as a subject of methodological reflection]. Psykholohiia $i$ suspilstvo [Psychology and society], 3, 72-85. (ukr.).

25. Furman, A. V. (2005). Systema innovatsiinoi osvitnoi diialnosti modulno-rozvyvalnoi shkoly ta yii kompleksna ekspertyza [The system of innovative educational activity of a modular-development school and its complex expertise]. Psykholohiia i suspilstvo [Psychology and society], 2, 29-75/ (ukr.).

26. Furman, A. V. \& Furman, O. Y. \& Shandruk, S. K. \& Co (2019). Vitakulturna metodolohiia: antolohiia. Do 25-richchia naukovoi shkoly profesora A. V. Furmana [Viticultural methodology: an anthology. To the 25th anniversary of professor A. V. Furman's Scientific School]. Ternopil: TNEU. (ukr.).

27. Furman, A. V. \& Furman, O. Y. \& Shandruk, S. K. \& Co (2019). Metodolohiia i psykholohiia humanitarnoho piznannia: kolektyvna monohrafiia. Do 25-richchia naukovoi shkoly profesora A. V. Furmana [Methodology and psychology of humanitarian cognition: a collective monograph. To the 25th anniversary of professor A. V. Furman's scientific school]. Ternopil: TNEU. (ukr.).

28. Furman, A. V. \& Shandruk, S. K. (2014a). Orhanizatsiyno-diyalnisni ihry u vyshchiy shkoli [Organizational-activity games in high school]. Ternopil: TNEU. (ukr.).

29. Furman, A. V. \& Shandruk, S. K. (2013). Sotsiema yak evrystychnyi kontsept zahalnoi sotsialnoi teorii [Sotsiema as a heuristic concept of general social theory]. Psykholohiia i suspilstvo [Psychology and society], 1, 5774. (ukr.).

30. Furman, A. V. \& Shandruk, S. K. (2014). Sutnist hry yak uchynennya [The essence of the game as commit]. Ternopil: TNEU. (ukr.).

31. Furman (Humeniuk), O. Y. (2012). Metodolohiia piznannia osvitnoho vchynku v konteksti innovatsiino-psykholohichnoho klimatu [Methodology of cognition of educational activity in the context of innovationpsychological climate]. Psykholohiia i suspilstvo [Psychology and society], 1, 47-81. (ukr.).

32. Furman (Humeniuk), O. Y. (2008). Teoriia i metodolohiia innovatsiino-psykholohichnoho klimatu zahalnoosvitnoho zakladu [Theory and methodology of innovation-psychological climate of secondary school]. Yalta-Ternopil: Pidruchnyky i posibnyky. (ukr.).

33. Furman, O. Y. (2015). Psykholohichni parametry innovatsiino-psykholohichnoho klimatu zahalnoosvitnoho navchalnoho zakladu [Psychological parameters of innovation-psychological climate of a comprehensive educational institution]. Odesa: DZ «Pivdennoukrainskyi natsionalnyi pedahohichnyi universytet imeni K. D. Ushynskoho». (ukr.).

34. Furman, O. Y. (2018). Ia-kontseptsiia yak predmet bahatoaspektnoho teoretyzuvannia [Self-concept as the subject of multidimensional theorizing]. Psykholohiia i suspilstvo [Psychology and society], 1-2, 38-67. (ukr.).

35. Shchedrovytskyi, H. P. (2005). Skhema myslediialnosti - systemno-strukturna budova, znachennia i zmist [The scheme of mentality - the system-structural structure, meaning and content]. Psykholohiia $i$ suspilstvo [Psychology and society], 4, 29-39. (ukr.).

36. Petrovskiy, A. V. \& Yaroshevskiy, M. G. (2001). Teoreticheskaya psihologiya [Theoretical psychology]. Moscow: Izd. centr «Akademiya». (rus.).

37. Shchedrovitskiy, P. H. \& Danylova, V. L. (Eds.). (2010). Georgiy Petrovich Shchedrovitskiy. Moscow: ROSSPEN. (rus.).

38. Shchedrovitskiy, G. P. (1995). Izbrannye trudy [Selected Works]; Piskoppel, A. A. \& Shchedrovitskiy, L. P. (Eds.) Moscow: Shk. kult. Politiki. (rus.).

39. Hayek, F. A. (2017). The Sensory Order and Othen Writings the Foundations of Theoretical Psychology. University of Chicago Press.

40. Teo, T. (2018). Outline of Theoretical Psychology (Critical Investigations). McMillan. 


\section{Anantoliy V. Furman \\ METATHEORETICAL RECONSTRUCTION OF THE CANONIC PSYCHOLOGY SUBJECT FIELD}

Science as a sphere of cognitive creativity and spiritual production of rational knowledge is based on the spacious connection of original rules, norms, canons (from gr. kanon - rule) which have been produced and tested by the heirs of mankind for centuries. The proposed methodological research is devoted to the analytical restoration and reflexive substantiation of the subject field of canonic psychology as one of the top creative achievements of the prominent Ukrainian psychologist-thinker of the second half of the XX century Academician Volodymyr Andriyovych Romenets (1926-1998). The novelty of this epistemic progress relates to several aspects of the constructive solution to this problem. Firstly, canonic psychology is considered as a post-action integration result of the development of three basic theoretical sources or disciplines - the history of world psychology, general psychology, and numerous psychological theories of some psychic event-phenomena (installations, attitude, unconscious, experience, game, personality, etc.), that is, it removes at the metatheoretical level (denies and at the same time saves in a transformed image) their content in more capacious, synthetic, compressed form. Secondly, due to the complexity of the problem covered, is chosen a multimodal tool, adequate for the way of how to solve it-a cyclicaction approach, the methodological optics of which contains four principles, six regularities and a number of derivative standards for the deployment of reflective thought-activity. Thirdly, the four main segments of the subjectivation of canonic psychology are subjected to analysis: as a philosophic-psychological direction for the development of modern human studies, as a scientific outlook «transition from the XX to the XXI century in psychological thought», as a metasystem of fundamental (basic to the foundations and the essence of human being) psychological knowledge, as the main course of the development of theoretical psychology by intellectual and semantic means of its self-reflection. Fourthly, canonic psychology, focusing on the study and construction of model phenomena and events of human life, gains cultural significance as a kind of worldview posture or meta-position of the vision and comprehension of the psychic. Therefore, it is concluded that this academic direction has a multiaspect, multi-segment subject that integrally contained into the subject field of theoretical psychology. It, as a complex philosophic-psychological metatheoretical construction, encompasses "all the prominent theories that arose in the historic-psychological discourse», giving them a true sense of cognition, evidenced by an action event. Finally, a four-level structural-functional cycle of any logically mature psychological canon is outlined, which makes clear the tendency-procedure of canonization of psychic phenomena and enriches the theoretical world of canonic psychology. It is proved that a well-grounded in the creative experience of inspired cognition for V. A. Roments, versatile and quite sufficient in its capabilities, a benchmark or even a worldview is the psychosophy of act as a methodology for the study of the sources, essence and canons-models of human existence, as actual - responsibly deed - interpenetration of psychology and philosophy of wisdom, after all, as a universal algorithm and methodological scheme of human daily progress to a fully component act, to a detailed, personally inspired and impregnated with a labile mind, teaching.

Keywords: canonic psychology, cyclic-action approach, subject field, reflexive methodologization, the world of theoretical psychology, methodological knowledge, meta-positioning, metatheory, canonization of theoretical systems, psychological canon, psychosophy of act, V. A. Romenets, P. A. Myasoid. 